\title{
SOCIAL COMPETENCE AND PSYCHOLOGICALVULNERABILITY AS PREDICTORS OF FACEBOOK ADDICTION
}

Begum SATICI, Mehmet SARICALI, Seydi Ahmet SATICI, Bahtiyar ERASLAN ÇAPAN

\author{
Turkish Aeronautical Association \\ Eskisehir, TURKEY \\ E-mail: begumunal.thk@gmail.com
}

\begin{abstract}
This study examined the predictive roles of social competence and psychological vulnerability in Facebook addiction. The study was carried out with 248 (139 women, 109 men, $M_{\text {age }}=21.5$ years, SD $=2.04$, and age range: $\left.18-37\right)$ Turkish university students. Participants completed the Turkish version of the Bergen Facebook Addiction Scale, the Psychological Vulnerability Scale, and the Perceived Social Competence Scale. The research data were analyzed by correlation and multiple regression analysis. Facebook addiction was in a positive correlation with psychological vulnerability and in a negative correlation with social competence. What's more, the findings indicated that psychological vulnerability and social competence were significant predictors of Facebook addiction. The contributions and limitations of the results were discussed.
\end{abstract}

Key words: Facebook addiction, social competence, psychological vulnerability

Bymeans of internet-based facilities people have experienced significantlydifferent communication practices in the last few decades. The development in web-based applications, which enable people to personalize the usage of these tools, is yet another dimension of this change. As a result of the development in social media (SNSs) such as Facebook, people can realize their ability to create their own profile, list other users with whom they share a connection and monitor their personal connections (Boyd, Ellison, 2007). On Facebook, people have started to join groups, introduce personal profiles, and create an event (Special, Li-Barber, 2012). Hence, Facebook features as one of the most popular SNSs that offer instant online communication and this fact helps Facebook to become an important part of dailyroutine and a practical way of maintaining relationships. Transformation in communication practices with the use of Facebook has become a mysterious field of interest for researchers because of the interactive and comprehensive nature of Facebook that attracts people. On the other hand, the usage of Facebook may turn even pathological (Andreassen et al., 2012; Kuss, Griffths, 2011). Peoplemay start using problematic behavioral patterns that can lead to negative psychological and physical outcomes. Because of this reason, the over-use of Facebook leading to a negative impact has become a current interest for researchers (Andreassen et al., 2012; Effendi, 2011; Kuss, Griffiths, 2011). Problematic Facebook use can be depicted as the inability to control and limit the amount of time one spends on Facebook that comprises a num-

DOI: $10.21909 /$ sp.2014.04.738 
ber of virtual activities (Cheung, Thadani, 2012). This statement is also considered as the operational definition ofFacebook addiction in this paper.

\section{Social Competence}

The transformation of communication practices with the emergence of SNSs has changed people's social networks sharply, and this dramatic change has caused social competence to become a significant research area. That is to say, communication practices have become online, more flexible, fast-moving, and fragmental in social contexts. Because social competence plays a role in people's social networks, investigating the effects of social competence in virtual social platforms may help to develop deeper understanding of the nature of social competence and the complexity of Facebook addiction. In this manner, social competence was defined as an individual's ability to generate skilled social performance in a goal-directed manner (Trower, 1982). This definition is also based on a notional operationalization of Social competence. Social competence was formerly treated as a dimension of personality and an intrinsic trait that individuals possess. However, in the 1960 s social competence was approached as a behavior rather than a trait in the field of psychology (Rathjen, Foreyt, 1980).

Social competence is open to be affected by external feedback in individual's social contexts. Therefore, in social media people may take immediate, unexpected, less controllable feedback independently from time and space. In this regard, investigating social competence together with Facebook addiction in the virtual world may help us make remarkable inferences.

\section{Psychological Vulnerability}

To understand the nature of vulnerability, its social context should be studied (Aday, 2001). Thus, in the frame of this investigation we take the virtual aspect of socialization into consideration. Psychological vulnerability has been treated as the individual's capacity to deal with mechanisms of maintaining emotional strength, in case of a pessimistic point of view, due to the lack of social support (Weisman, Worden, 1976). Psychological vulnerability can also be defined as a pattern of cognitive beliefs reflecting a dependence on achievement or external sources of affirmation for one's sense of selfworth (Sinclair, Wallston, 1999). That is to say, according to the postulations of this paper, the cognitive lens that an individual possesses in the context of social relations is among the two basic sources of psychological vulnerability. Empirical research has shown that, psychological vulnerability is negatively related to positive affect, social support, and self-efficacy and positively related to negative affect maladaptive coping behavior and perceived helplessness (Sinclair, Wallston, 1999). In this respect, Facebook has become a strong new socialization practice, which includes affirmations and disapprovals of others in individual lives. Hence, the affirmations and disapprovals of individuals in social settings have become very fragmental and uncontrollable.

\section{THE PRESENT STUDY}

Internet based applications, like Facebook, has been far less elaborated and it is an open field of research of new inference. In addition, comparing and investigating real social 
settings data with those in virtual settings may help obtain comparable data and create new theoretical constructions. In other words, there is a strong need for an investigation of Facebook as a social media, which is used by more than 800 million people throughout the world. To find an answer to the question why people use Facebook excessively and gain a comprehensive understanding of the problem, the sub-components that underlie the overuse of Facebook should be scrutinized. Understanding the nature of social competence in virtual social settings is important, therefore, one of the aims of this study is to investigate the predictable role of social competence in using Facebook, which is one of the most common SNSs which enables immediate and flexible feedback in larger contexts. In addition, psychological vulnerability, closely related to social and emotional aspects, needs to be examined because the answer to the question of whether psychological vulnerability is as predictive in virtual social contexts as in real context in terms of external feedback, can be illuminating. This study's aim is to investigate the relationship between social competence and psychological vulnerability and Facebook addiction. We have hypothesized that social competence will be associated negatively with Facebook addiction and psychological vulnerability will be associated positively with Facebook addiction.

\section{METHOD}

\section{Participants}

Participants were 248 (139 women, 109 men, $M_{\text {age }}=21.5$ years, $\mathrm{SD}=2.04$, and age range: 18-37) university students enrolled in the Faculty of Education and Faculty of Science at Anadolu University, Turkey. This study was conducted based on simple random sampling methods. The distribution of participants was as follows: $52(21 \%)$ were firstyear students, 86 (35\%) were second-year students, $59(24 \%)$ were third-year students, and $51(21 \%)$ were fourth-year students. The average time spent on the Internet on a typical weekday was reported to be 155 minutes $(\mathrm{SD}=105.6)$. In the selection of the participants, having a Facebook account was a prerequisite criterion.

\section{Measures}

The Bergen Facebook Addiction Scale (BFAS; Andreassen et al., 2012). The BFAS consists of 18 items (e.g., Used Facebook to reduce feelings of guilt, anxiety, helplessness, and depression?) and each item was answered on a $1-5$ scale that ranges from very rarely to very often. The sum of all scores yields a total score ranging from 18 to 90 , the higher scores indicating greater Facebook addiction. The Cronbach alpha coefficient of the BFAS was .83 and test-retest reliability coefficient was .82 for the original version. A Turkish adaptation of this scale was conducted by Akin et al. (2013). Results of confirmatory factor analysis indicated that the scale was well fit $\left(\chi^{2}=291.88, \mathrm{df}=118\right.$, $\mathrm{p}<0.001, \mathrm{RMSEA}=.061, \mathrm{CFI}=.95, \mathrm{GFI}=.92$, $\mathrm{IFI}=.95$, and $\mathrm{SRMR}=.040)$. The internal consistency reliability coefficient of the scale was .93 for the Turkish version. In the present study, Cronbach alpha coefficient was $\alpha=$ .90 .

Perceived Social Competence Scale (Anderson-Butcher, Iachini, Amorose, 2007). The scale has 6 items (e.g., I get along well with others) and each item ranges from 1 (not at all) to 5 (very much). It yields total scores 
from 6 to 30, where a higher score indicates a higher social competence level. The Cronbach alpha coefficient of the original version was .87. The Turkish version of the scale had been done by Akin et al. (2012). Results obtained from the confirmatory factor analyses demonstrated that 6 items yielded one factor as the original form and that the one-dimensional model was well fit $\left(\chi^{2}=7.34, \mathrm{df}=7, \mathrm{RMSEA}=.010, \mathrm{CFI}=1.00\right.$, $\mathrm{RFI}=0.99, \mathrm{IFI}=1.00, \mathrm{AGFI}=.98, \mathrm{GFI}=.99$, $\mathrm{NFI}=.99$, and $\mathrm{SRMR}=.018)$. The Cronbach alpha coefficient of the Turkish version was .80 .

Psychological Vulnerability Scale (Sinclair, Wallston, 1999). The scale comprised of 6 items (e.g., I need approval from others to feel good about myself). Each item was presented on a 5-point Likert-type scale $(1=$ applies to me to $5=$ definitely applies to me). A total score ranges from 6 to 30; a higher score indicates a higher psychological vulnerability level. The Cronbach alpha coefficient of the original version ranged from .71 to .87 for different samples. The Turkish adaptation of this scale was done by Akin and Eker (2011). Results obtained from the confirmatory factor analyses demonstrated that 6 items yielded one factor as the original form and that the one-dimensional model was well fit $\left(\chi^{2}=7.82, \mathrm{df}=9, \mathrm{NFI}=.97, \mathrm{CFI}=1.00\right.$, $\mathrm{GFI}=.99, \mathrm{AGFI}=.98, \mathrm{RFI}=.95, \mathrm{RMSEA}=$ .000 , and $\mathrm{SRMR}=.025)$. The amount of total variance explained by one factor was $36 \%$. The Cronbach alpha coefficient of the Turkish version was .75.

\section{Procedure and Data Analysis}

The data collection tools used in the study were given to the students in one booklet and applied in one session in the spring term of 2012-2013 academic year. Data collection took place between March and April 2013. It took a participant nearly 10 minutes to complete the data set. Participants participate voluntarily and are free to fill out questionnaires without pressure and based on their own affects and ideas. Completion of the questionnaires was anonymous and there was a guarantee of confidentiality. Researchers encouraged the students to keep their answers confidential and reminded them not to talk to their classmates about their answers. The instruments were administered to the students in groups in the classrooms. The measures were counterbalanced in administration. For counterbalancing, the order of the scales was altered after every fifteen applications. Prior to administration of measures, all participants were informed about the purpose of the study.

In this study, the analysis of the data was carried out using Pearson's correlation and stepwise regression method analysis. Before carrying out the analysis, normality, homogeneity, Mahalanobis distance values, singularity, tolerance, VIF, and Durbin-Watson hypothesis were controlled. An alpha coefficient of .05 was used for all statistical tests. The analyses were applied via SPSS 15 for windows.

\section{RESULTS}

Means, standard deviations, and inter-correlation for all the study variables are presented in Table 1. Mean scores indicate that the participants tended to exhibit a moderate level of psychological vulnerability $(\mathrm{M}=$ 16.27, $\mathrm{SD}=4.46$ ). It can be inferred that in our sample, Facebook addiction level was relatively low according to the mean scores $(\mathrm{M}=30.71, \mathrm{SD}=10.97)$ but social compe- 
tence level was relatively high $(\mathrm{M}=25.09$, $\mathrm{SD}=3.65)$.

As our results indicate, Facebook addiction is significantly negatively correlated with social competence, $r=-.39,95 \%$ C.I. $[-.49,-.27]$ and significantly positively correlated with psychological vulnerability, $\mathrm{r}=.41$, $95 \%$ C.I. [.29, .51].

Social competence and psychological vulnerability were used in a stepwise multiple regression analysis to predict Facebook addiction. The results are shown in Table 2.

According to the results of multiple regression analysis, summarized in Table 2, the model was statistically significant, $\mathrm{F}_{(1,216)}=$ $38.871, \mathrm{p}<.001$, and accounted for approxi- mately $27 \%$ of the variance of Facebook addiction $\left(\mathrm{R}^{2}=.266\right.$, Adjusted $\left.\mathrm{R}^{2}=.259\right)$. Psychological vulnerability entered the equation first, accounting for $17 \%$ of the variance in predicting Facebook addiction $\left(\mathrm{R}^{2}=.167\right.$, adjusted $\left.\mathrm{R}^{2}=.163\right)$. Then, social competence entered on the second step, accounting for an additional $10 \%$ of variance $\left(\Delta \mathrm{R}^{2}=.098\right)$. The standardized beta coefficients in the last model indicated that psychological vulnerability $\left(\beta=.35, \mathrm{t}_{(248)}=5.83, \mathrm{p}<.001\right)$ and social competence $\left(\beta=-.32, \mathrm{t}_{(248)}=-5.37, \mathrm{p}<\right.$ $.001)$ significantly predicted Facebook addiction. Psychological vulnerability received the strongest weight in the model followed by social competence.

Table 1. Descriptive statistics and inter-correlations of the variables

\begin{tabular}{|l|c|c|c|}
\hline Variables & $\begin{array}{c}\text { Facebook } \\
\text { Addiction }\end{array}$ & $\begin{array}{c}\text { Social } \\
\text { Competence }\end{array}$ & $\begin{array}{c}\text { Psychological } \\
\text { Vulnerability }\end{array}$ \\
\hline Facebook Addiction & 1.00 & & \\
\hline Social Competence & $-.39^{* *}$ & 1.00 & \\
\hline Psychological Vulnerability & $.41^{* *}$ & $-.19^{* *}$ & 1.00 \\
\hline Mean & 30.71 & 25.09 & 16.27 \\
\hline Standard Deviation & 10.97 & 3.65 & 4.46 \\
\hline
\end{tabular}

Note: ${ }^{* *} \mathrm{p}<.01$

Table 2. Results of stepwise regression analysis related to the prediction of Facebook addiction

\begin{tabular}{|l|c|c|c|c|c|c|c|c|}
\hline & \multicolumn{2}{|c|}{$\begin{array}{c}\text { Unstandardized } \\
\text { Coefficients }\end{array}$} & \multicolumn{2}{|c|}{$\begin{array}{c}\text { Standardized } \\
\text { Coefficients }\end{array}$} & & & \\
\hline Variables & $\mathrm{B}$ & $\mathrm{SE}_{\mathrm{B}}$ & $\beta$ & $\mathrm{t}$ & $\mathrm{R}$ & $\mathrm{R}^{2}$ & $\mathrm{~F}$ \\
\hline Step 1 & \multicolumn{7}{|c|}{$\beta$} & \multicolumn{2}{|c|}{} \\
\hline Psychological vulnerability & 1.000 & .153 & .409 & $6.58^{*}$ & .41 & .17 & $43.33^{*}$ \\
\hline Step 2 & .854 & .147 & .347 & $5.83^{*}$ & \multirow{2}{*}{.51} & \multirow{2}{*}{.27} & \multirow{2}{*}{$38.87^{*}$} \\
\hline Psychological vulnerability & -.962 & .179 & -320 & $-5.37^{*}$ & & &
\end{tabular}

Note: ${ }^{*} \mathrm{p}<.001$ 


\section{DISCUSSION}

The purpose of the current study was to investigate the relationships between psychological vulnerability, social competence and Facebook addiction. It was supposed that social competence would be associated positively and psychological vulnerability negatively with Facebook addiction. The results show that social competence and psychological vulnerability are significant predictors of Facebook addiction. In other words, higher level of social competence reveals lower level of Facebook addiction, and higher level of psychological vulnerability reveals higher level of Facebook addiction.

There has been no satisfactory investigation to show a relationship between Facebook addiction and psychological concept. Social anxiety has been found to be related to low social competence (Beidel, Turner, 1998), as the results of the current study indicate. People may arrange their virtual social environment in such a way that they can deal with the negative impact of their emotions, with the help of the flexible nature of virtual social networks. Another study has shown that, depressed people perceive themselves as less socially competent (Dykman et al., 1991; Jacquez, Cole, Searle, 2004; Smari, Petursdottir, Porsteinsdottir, 2001). On the other hand, depression was found to be correlated to internet addiction that compromise Facebook addiction (Ceyhan, Ceyhan, 2008; Koc, Gulyagci, 2013; Young, Rodgers, 1998). In this perspective, the findings of the current study are indirectly consistent with previous investigations.

This study's findings can be considered reasonable, in terms of some theoretical notions. For instance, social compensation theory, which postulated that people use media to fulfill their social needs that are unmet in everyday life (Davis, Kraus, 1989), provided an illuminating perspective, by means of an understanding of the relation between Facebook addiction and psychological vulnerability. According to this theory, people may utilize their virtual networks to compensate for gaps that occur in real social life (McKenna, Green, Gleason, 2002). The interactional pattern that may stimulate psychological vulnerability may diminish on Facebook.

In previous research studies, psychological vulnerability was found to negatively correlate with life satisfaction and well-being (Sinclair, Wallstaon, 1992). Well-being was also found to be negatively related to internet addiction (Kalpidou, Costin, Morris, 2011). It can be inferred that the current findings correspond to previous research results.

In conclusion, in terms of the understanding the nature of Facebook addiction, social competence, which affects feedback of others, and psychological vulnerability, which is closely related to affirmation by others, was approached under the same framework in the scope of this investigation. In addition, social competence and psychological vulnerability, consistent concepts within a broader perspective, were found to be negative predictors of Facebook addiction, in line with previous investigations.

Major limitations associated with the current study need to be tackled. Firstly, this study was conducted with the students of only one university in Turkey. In terms of generalizability of this study, our sample is very limited. A replication of this study, to target other student populations of different age groups and cultures, should be carried 
out in order to generate a more tangible relationship among Facebook addiction, social competence, and psychological vulnerability. Secondly, a correlational research design was used in the current study with crosssectional sample. Hence, no cause-effect relationship exists between the variables. Future studies, using a longitudinal and experimental design, may specify the directionality of the relationships among the variables. Lastly, all data were based on the students' self-report responses. Using multiple methods, such as a mix method research design, may be useful in decreasing the "subjectivity" limitation of the findings and enhancing the validity of the results. Consequently, despite these limitations, this study brought an important contribution. The results indicated that social competence and psychological vulnerability are important factors in Facebook addiction. Current findings help improve our knowledge about the nature of Facebook addiction. Finally, this study suggests that universities should offer services, which would help students in their social competence, in order to eradicate Facebook addiction. Under the auspice of mental health care services, universities need to develop intervention programs, such as, psychotherapy groups, group counseling, in order to support students who suffer from psychological vulnerability. In this way, Facebook addiction can be prevented in a proactive manner.

Received December 22, 2013

\section{REFERENCES}

ADAY, L., 2001, At risk in America. San Francisco, CA: Jossey-Bass.

AKIN, A., EKER, H., 2011, Turkish version of the Psychological Vulnerability Scale: A study of validity and reliability. Paper presented at the 32th
International Conference of the Stress and Anxiety Research Society (STAR), July, 18-20, Münster, Germany.

AKIN, A., AKIN, U., GEDIKSIZ, E., ARSLAN, S., SARICAM, H., YALNIZ, A., 2012, Algllanan Sosyal Yetkinlik Ölçeği Türkçe Formu: Geçerlik ve güvenirlik çalışması. III. Ulusal Eğitimde ve Psikolojide Ölçme ve Değerlendirme Kongresi, 1921 September, Bolu, Turkey.

AKIN, A., DEMIRCI, İ., AKIN, U., OCAKÇI, H., AKDENIZ, C., AKBAŞ, Z.Ş., 2013, Turkish version of the Facebook Addiction Scale. Paper presented at the $13^{\text {th }}$ European Congress of Psychology (ECP 2013), 9-12 July, Stockholm, Sweden.

ANDERSON-BUTCHER, D., IACHINI, A.L., AMOROSE, A.J., 2007, Initial reliability and validity of perceived social competence scale. Research on Social Work Practice, 18, 1, 47-54.

ANDREASSEN, C.S., TORSHEIM, T., BRUNBORG, G.S., PALLESEN, S., 2012, Development of a Facebook Addiction Scale. Psychological Reports, 110, 1-17.

BEIDEL, D.C., TURNER, S.M., 1998, Shy children, phobic adults: Nature and treatment of social phobia. Washington, DC: APA.

BOYD, D.M., ELLISON, N.B., 2007, Social network sites: Definition, history, and scholarship. Journal of Computer-Mediated Communication, 13, 1, 210-230.

CEYHAN, A.A., CEYHAN, E., 2008, Loneliness, depression, and computer self-efficacy as predictors of problematic internet use. CyberPsychology \& Behavior, 11, 6, 699-701.

CHEUNG, C.M., THADANI, D.R., 2012, The impact of electronic word-of-mouth communication: A literature analysis and integrative model. Decision Support Systems, 54, 1, 461-470.

DAVIS, M.H., KRAUS, L.A., 1989, Social contact, loneliness, and mass media use: A test of two hypotheses. Journal of Applied Social Psychology, 19, 13, 1100-1124.

DYKMAN, B.M., HOROWITZ, L.M., ABRAMSON, L.Y., USHER, M., 1991, Schematic and situational determinants of depressed and nondepressed students' interpretation of feedback. Journal of Abnormal Psychology, 100, 45-55.

EFFENDI, M., 2011, Facebook: The phenomenon of bringing addiction? Journal of Communication and Computer, 8, 925-930.

JACQUEZ, F.M., COLE, D.A., SEARLE, B., 2004, Self-perceived competence as a mediator between maternal feedback and depressive symp- 
toms in adolescents. Journal of Abnormal Child Psychology, 32, 355-367.

KALPIDOU, M., COSTIN, D., MORRIS, J., 2011, The relationship between Facebook and the wellbeing of undergraduate college students. CyberPsychology, Behavior, \& Social Networking, 14, 4, 183-189.

KOC, M., GULYAGCI, S., 2013, Facebook addiction among Turkish college students: The role of psychological health, demographic, and usage characteristics. CyberPsychology, Behavior, \& Social Networking, 16, 4, 279-284.

KUSS, D., GRIFFITHS, M., 2011, Online social networking and addiction - A review of the psychological literature. International Journal of Environmental Research and Public Health 8, 35283552 .

MCKENNA, K.Y., GREEN, A.S., GLEASON, M.E., 2002, Relationship formation on the Internet: What's the big attraction? Journal of Social Issues, 58, 1, 9-31.

RATHJEN, D.P., FOREYT, J.P., 1980, Social competence: Interventions for children and adults. New York: Pergamon Press.
SINCLAIR, V.G., WALLSTON, K.A., 1999, The development and validation of the psychological vulnerability scale. Cognitive Therapy and Research, 23, 2, 119-129.

SMARI, J., PETURSDOTTIR, G., PORSTEINSDOTTIR, V., 2001, Social anxiety and depression in adolescents in relation to perceived competence and situational appraisal. Journal of Adolescence, 24, 2, 199-207.

SPECIAL, W.P., LI-BARBER, K.T., 2012, Selfdisclosure and student satisfaction with Facebook. Computers in Human Behavior, 28, 624-630.

TROWER, P., 1980, Situational analysis of the components and processes of behavior of socially skilled and unskilled patients. Journal of Consulting and Clinical Psychology, 48, 3, 327339.

WEISMAN, A.D., WORDEN, J.W., 1976, The existential plight in cancer: Signicance of the first 100 days. The International Journal of Psychiatry in Medicine, 7, 1, 1-15.

YOUNG, K.S., RODGERS, R.C., 1998, The relationship between depression and Internet addiction. CyberPsychology \& Behavior, 1, 25-28.

\title{
SOCIÁLNE KOMPETENCIE A PSYCHOLOGICKÁ ZRANITEL'NOSŤ AKO PREDIKTORY ZÁVISLOSTI OD FACEBOOKU
}

\author{
B. Satici, M. Saric a 1 i, S. A. S a t i c i, B. Eras lan C a pa n
}

Súhrn: V štúdii sa skúmali prediktívne vplyvy sociálnych kompetencií a psychologickej zranitel'nosti na závislost' od Facebooku. Výskumu sa zúčastnilo 248 (139 žien, 109 mužov, M $=21,5$ rokov, $\mathrm{SD}=2,04$, vekové rozmedzie: 18-37) tureckých vysokoškolákov. Respondentom sme administrovali tureckú verziu Bergen Facebook Addiction Scale, Psychological Vulnerability Scale, a Perceived Social Competence Scale. Dáta boli analyzované korelačnou a viacnásobnou regresnou analýzou. Závislost' od Facebooku pozitívne korelovala s psychologickou zranitel'nost'ou a negatívne so sociálnymi kompetenciami. Okrem toho zistenia naznačujú, že psychologická zranitel'nost' a sociálne kompetencie signifikantne predikovali závislost' od Facebooku. Diskutujeme tiež aj prínosy a limity výsledkov výskumu. 